\title{
ANALIZA PRZYCZYN ODMÓW PRZYJĘCIA PACJENTÓW Z ROZLEGLYMI RANAMI I AMPUTACJAMI RĄK, ZGLASZANYCH DO SERWISU REPLANTACYJNEGO
}

\section{AN ANALYSIS OF THE CAUSES OF REFUSAL OF ADMISSION TO PATIENTS WITH SEVERE INJURIES AND AMPUTATIONS OF THE HAND REFERRED TO THE REPLANTATION SERVICE}

\author{
Klinika Chirurgii Ogólnej i Chirurgii Ręki Pomorskiego Uniwersytetu Medycznego w Szczecinie \\ ul Unii Lubelskiej 1, 71-252 Szczecin \\ Kierownik: prof. dr hab. n. med. Andrzej Żyluk \\ ${ }^{1}$ Studenckie Koło Naukowe przy Klinice Chirurgii Ogólnej i Chirurgii Ręki PUM w Szczecinie \\ Opiekunowie: prof. dr hab. n. med. Andrzej Żyluk, dr n. med. Piotr Puchalski
}

\begin{abstract}
Summary
Introduction: Total or partial upper limb amputation significantly reduces ability of normal functioning in the society. Development of microsurgical skills enabled to replantation of the amputated limb (or part) and to regain its partial or sometimes full function.

Material and methods: The study analyses the causes of refusal of admission to 55 of 141 patients referred to the replantation service of the Department of General and Hand Surgery PUM, over the period 2012-2013.

Results: The causes of denied admission included: injury without compromise of blood supply to the limb $(35 \%)$, distal amputations $(27 \%)$, crush injuries $(11 \%)$, single finger amputation (9\%), severe damage of the amputated part (9\%) and lower limb amputations (5\%). The age of the patient had no significant influence on the decision to refuse admission. The distance between the referring hospital and the replantation centre was statistically significantly shorter in accepted cases $(252 \mathrm{~km}$ vs $496 \mathrm{~km}$, $\mathrm{p}<0.05$ ).

Conclusion: Our outcomes show a variety of causes of refusal of admission to patients with severe trauma and amputation of the hand. The main factors influencing decision making regarding admission or denial were associated with the actual danger to the survival of the
\end{abstract}

involved limb, and estimation/calculation of the chance for limb saving.

K e y w o r d s: upper limb amputation - replantation.

\section{Streszczenie}

Wstęp: Utrata kończyny górnej lub jej części ogranicza w sposób istotny możliwość normalnego funkcjonowania w społeczeństwie. Osiągnięcia mikrochirurgii pozwoliły na przyszycie odciętej kończyny lub jej części i odzyskanie jej częściowej, a niekiedy pełnej sprawności.

Materiat $i$ metody: Analizie poddano 55 przypadków odmów przyjęć spośród 141 pacjentów zgłoszonych w ramach serwisu replantacyjnego do Kliniki Chirurgii Ogólnej i Chirurgii Ręki Pomorskiego Uniwersytetu Medycznego w Szczecinie w latach 2012-2013.

Wyniki: Główne przyczyny odmów stanowiły rany bez zaburzeń ukrwienia kończyny (35\%), dystalne amputacje palców (27\%), zmiażdżenia (11\%), amputacje pojedynczego palca, nie kciuka (9\%), znaczne uszkodzenia części amputowanej (9\%) i amputacje kończyny dolnej (5\%). Wiek chorych nie miał istotnego znaczenia dla decyzji o odmowie przyjęcia. Średnia odległość szpitala zgłaszającego od ośrodka replantacyjnego była statystycznie istotnie 
mniejsza w grupie pacjentów przyjętych niż w grupie odmów (252 km vs $496 \mathrm{~km}, \mathrm{p}<0,05)$.

Wnioski: Wyniki analizy wskazują na różne przyczyny odmów przyjęcia chorych z urazami i amputacjami rąk w ramach serwisu replantacyjnego. Głównymi czynnikami wpływającymi na decyzję o przyjęciu lub odmowie było istnienie lub brak zagrożenia dla przeżycia uszkodzonej kończyny i ocena realnych szans na jej uratowanie.

H a s $\nmid$ a: amputacja kończyny górnej - replantacja.

\section{Wstęp}

Amputacja kończyny jest dla człowieka bardzo traumatyzującym i okaleczającym zdarzeniem, które często zmienia jego życie zawodowe i osobiste. Utrata kończyny górnej lub jej części ogranicza w sposób istotny możliwość normalnego funkcjonowania w społeczeństwie. Osiągnięcia mikrochirurgii umożliwiły naprawienie tego dotychczas nieodwracalnego zdarzenia, czyli pozwoliły na przyszycie odciętej kończyny lub jej części i odzyskanie częściowej, a niekiedy pełnej sprawności.

W 2010 r. z inicjatywy Zarządu Polskiego Towarzystwa Chirurgii Ręki utworzono serwis replantacyjny, czyli stały dyżur dla przypadków amputacji rąk pełniony przez trzy ośrodki: w Trzebnicy, Poznaniu i Szczecinie [1, 2]. Każdego dnia dyżur replantacyjny pełni inna jednostka, która przyjmuje z całego obszaru kraju zgłoszenia amputacji rąk (od poziomu śródręcza), kciuków i kilku palców. Zakres działalności serwisu obejmuje ponadto niektóre zmiażdżenia i oskalpowania rąk wymagające zaopatrzenia mikrochirurgicznego lub pokrycia ubytków płatami [3].

Organizacja serwisu jest następująca: kontakt lekarza zgłaszającego przypadek amputacji z lekarzem dyżurnym oddziału dyżurnego następuje bezpośrednio lub za pośrednictwem Lotniczego Pogotowia Ratunkowego, które jest poinformowane o tym, który oddział pełni dyżur. Wymagane jest, aby przypadek zgłaszał lekarz specjalista, chirurg lub ortopeda posiadający doświadczenie w realnej ocenie stanu odciętej kończyny i chorego, tzn. czy kończyna nadaje się do replantacji, a chory do transportu. Bezwzględnie wymagane jest przesłanie (za pomocą wiadomości MMS) zdjęcia odciętej kończyny i kikuta, a w przypadku zmiażdżenia także zdjęcia RTG. Na podstawie otrzymanej dokumentacji fotograficznej i rozmowy z kompetentnym lekarzem z ośrodka kierującego podejmowana jest decyzja o przyjęciu lub odmowie przyjęcia zgłoszenia. W pierwszym przypadku jednostka kierująca chorego organizuje transport, najczęściej lotniczy. Nawet w przypadku akceptacji zgłoszenia przez ośrodek dyżurny należy obliczyć czas transportu.

$\mathrm{Z}$ opisu procedury zgłaszania przypadków amputacji do serwisu wynika, że określona ich cześć może nie zostać zaakceptowana $z$ różnych powodów.

Celem pracy była analiza przyczyn odmów przyjęć pacjentów zgłoszonych do serwisu replantacyjnego.

\section{Material i metodyka}

Analizie poddano 141 przypadków zgłoszeń do Kliniki Chirurgii Ogólnej i Chirurgii Ręki Pomorskiego Uniwersytetu Medycznego w Szczecinie (PUM) pacjentów z amputacjami lub innymi rozległymi urazami kończyny górnej urazów w obrębie kończyny górnej, w latach 2012-2013. W grupie było 125 mężczyzn (89\%) i 16 kobiet (11\%) w wieku 2-82 lat (średnia 42 lata). Analizie poddano czynniki, które stanowiły podstawę podjęcia decyzji odmownej u 55 osób (39\%). W przypadkach całkowitych amputacji były to:

- zły stan amputowanej części ręki, który nie dawał realnych szans na skuteczną replantację,

- amputacje pojedynczych palców (taki uraz nie wchodzi w zakres działalności serwisu),

- amputacje dystalnych części palców,

- zły stan ogólny chorego z powodu towarzyszących urazów (np. amputacja w przebiegu urazu wielonarządowego),

- podeszły wiek chorego.

W przypadkach amputacji częściowych, a właściwie rozległych ran, ale bez zaburzeń ukrwienia ręki, odmowa była uzasadniana brakiem zagrożenia dla przeżycia kończyny. Takie urazy nie wymagają pilnej mikrochirurgicznej naprawy naczyniowej, tylko leczenia rekonstrukcyjnego, które może być przeprowadzone w ośrodkach bliższych miejsca urazu i niekoniecznie od razu. Analizę statystyczną przeprowadzono za pomocą nieparametrycznego testu istotności U Manna-Whitneya.

\section{Wyniki}

Z ogólnej liczby 141 zgłoszeń zaakceptowano 86 (61\%), a w 55 przypadkach (39\%) odmówiono przyjęcia. Przyczyny odmów były następujące: rozległa rana/rany ręki bez zaburzeń ukrwienia i zagrożenia dla przeżycia - 19 przypadków (35\%), amputacja dystalnej części palca (lub palców), zwykle od poziomu stawu międzypaliczkowego bliższego - 15 (27\%), zmiażdżenie palca lub ręki niewymagające leczenia mikrochirurgicznego - $6(11 \%)$, zniszczenie amputowanej kończyny lub jej części - 5 (9\%), amputacja pojedynczego palca niebędącego kciukiem - 5 (9\%), uraz w obrębie kończyny dolnej - 3 (5\%), ciężki stan chorego z powodu towarzyszącego amputacji ręki urazu głowy $1(2 \%)$, podeszły wiek i obciążenie poważnymi chorobami towarzyszącymi - $1(2 \%)$.

Porównano dane demograficzne i strukturę urazów w grupach chorych, których przyjęto do replantacji i którym odmówiono przyjęcia. Wyniki porównania zsumowano w tabeli 1 . Nie stwierdzono istotnie statystycznych różnic w zakresie tych parametrów (test U Manna-Whitneya, p > 0,05), z wyjątkiem odległości od szpitala zgłaszającego od ośrodka replantacyjnego, większej w grupie pacjentów, którym odmówiono przyjęcia (śr. 496 km vs $252 \mathrm{~km}, \mathrm{p}<0,05)$. 
T a b e 1 a 1. Porównanie danych demograficznych i struktury urazów w grupach chorych, których przyjęto do replantacji i którym odmówiono przyjęcia

\begin{tabular}{|c|c|c|}
\hline Cecha & Przyjęcie & Odmowa \\
\hline Liczba chorych & $86(61 \%)$ & $55(39 \%)$ \\
\hline Wiek (średnia) & 42 lata & 41 lat \\
\hline Rodzaj urazu & \multicolumn{2}{|c|}{ Liczba chorych } \\
\hline Amputacje całkowite & 49 & 32 \\
\hline Amputacje częściowe & 11 & 4 \\
\hline Rany szarpane & 16 & 14 \\
\hline Zmiażdżenia & 10 & 5 \\
\hline Poziom urazu & \multicolumn{2}{|c|}{ Liczba chorych } \\
\hline Paliczek dalszy & 5 & 1 \\
\hline Paliczek środkowy & 33 & 11 \\
\hline Paliczek bliższy & 21 & 14 \\
\hline Śródręcze & 5 & 10 \\
\hline Nadgarstek & 14 & - \\
\hline Przedramię & 2 & 4 \\
\hline Ramię & 0 & 1 \\
\hline Kończyna dolna & 0 & 3 \\
\hline Liczba uszkodzonych palców & \multicolumn{2}{|c|}{ Liczba chorych } \\
\hline 1 & 28 & 21 \\
\hline 2 & 11 & 8 \\
\hline 3 & 7 & 4 \\
\hline 4 & 11 & 2 \\
\hline 5 & 1 & - \\
\hline $\begin{array}{l}\text { Średnia odległość ośrodka } \\
\text { zgłaszającego do kliniki }\end{array}$ & $252 \mathrm{~km}$ & $496 \mathrm{~km}$ \\
\hline
\end{tabular}

\section{Dyskusja}

Najczęstszą przyczyną odmowy przyjęcia pacjenta było stwierdzenie nie amputacji, ale rozległej rany bez zaburzenia ukrwienia uszkodzonej kończyny, co było równoznaczne $\mathrm{z}$ brakiem zagrożenia dla jej przeżycia. W takiej sytuacji nie jest konieczna procedura mikrochirurgiczna w trybie nagłym odtwarzająca ukrwienie w celu ratowania kończyny. Jest kilka możliwości leczenia takiego chorego: wykonanie operacji rekonstrukcyjnej w szpitalu, do którego trafił, przesłanie pacjenta do ośrodka referencyjnego w województwie (zwykle jest to Wojewódzkie Centrum Urazowe) lub proste zaopatrzenie rany wraz z hemostazą i znalezienie ośrodka, który wykona rekonstrukcję w późniejszym terminie. Takie postępowanie nie wiąże się $\mathrm{z}$ większym ryzykiem utraty czynności kończyny, ponieważ wyniki odroczonego (zwykle do 2 tyg.) zaopatrzenia urazu nie są istotnie gorsze od pierwotnej naprawy. Należy pamiętać, że w Polsce codziennie zdarza się kilka takich urazów. Serwis replantacyjny służy do ratowania kończyny, która nie przeżyłaby bez rekonstrukcji mikrochirurgicznej, natomiast urazy, które mogą być (lepiej lub gorzej) zaopatrzone gdzie indziej, powinny być leczone w innym trybie, np. w macierzystym województwie. Takie procedury jak zespolenie kości, zszycie ścięgien i nerwów, choć wymagające doświadczenia i czasochłonne, są w zakresie kompetencji każdego oddziału ortopedycznego. Klinika Chirurgii Ogólnej i Chirurgii Ręki PUM od 10 lat prowadzi systematyczne kursy doskonalące $\mathrm{z}$ chirurgii ręki i chirurgii rekonstrukcyjnej dla lekarzy specjalizujących się w ortopedii z całej Polski. Uczestnictwo w tygodniowym kursie pozwala na zdobycie podstawowych umiejętności zaopatrywania urazów.

Drugą najczęstszą przyczyną był poziom urazu - dystalnie od stawu międzypaliczkowego bliższego. Dotyczyło to zwykle pojedynczego palca, ale także kilku palców. W piśmiennictwie jest wiele przykładów wykonania skutecznych replantacji na tym, a nawet dalszym poziomie - wyniki czynnościowe takich replantacji są dobre $[4,5,6]$. Jednak technicznie taka operacja jest bardzo trudna, ponieważ zespala się naczynia o średnicy poniżej $1 \mathrm{~mm}$. O ile zszycie tętnicy palcowej jest możliwe dla „przeciętnego” mikrochirurga, o tyle naprawa żyły jest znacznie trudniejsza i rzadko się udaje. Żyły są zwykle cieńsze, ich ściana jest wiotka i łatwo naczynie po prostu zaszyć. Dlatego odmawia się przyjęcia pacjentów z odległych rejonów Polski, ograniczając się do wykonywania tych operacji u chorych z województwa, także w celu szkolenia lekarzy kliniki w trudnych technicznie replantacjach. Staramy się także podejmować próby dystalnych replantacji u dzieci, z różnym powodzeniem.

Zmiażdżenia kończyny, jej części lub palców były trzecią co do częstości przyczyną odmów. Zmiażdżenie nie jest urazem, który wymaga leczenia mikrochirurgicznego, a przeżycie kończyny w małym stopniu zależy od umieszczenia pacjenta w ośrodku wykonującym replantacje. Najczęściej w tych przypadkach zalecano wykonanie zespoleń kostnych i leczenia zapobiegającego wykrzepianiu w naczyniach zmiażdżonej części ręki. Ważnym czynnikiem wpływającym na odzyskanie dobrej czynności ręki po takim urazie, w przypadku przeżycia kończyny, jest jak najszybsze rozpoczęcie uruchamiania palców, na co zwracano uwagę w rozmowach z lekarzami ośrodka kierującego. Inną przyczyną odmowy w tych przypadkach jest fakt, że kilka takich przypadków zdarza się codziennie w całym kraju i ich przesyłanie do ośrodka replantacyjnego nie jest możliwe z powodów logistycznych. $Z$ danych zawartych w tabeli 1 wynika jednak, że do kliniki przyjęto $10 \mathrm{z} 15$ zgłoszonych chorych ze zmiażdżeniem; były to jednak przypadki urazów całej ręki lub kończyny zagrażające jej przeżyciu i niekiedy przebiegające z tzw. oskalpowaniem. Wyniki leczenia takich chorych opisano w innej pracy [3]. Inną opcją postępowania w takich przypadkach było przyjęcie pacjentów do kliniki po kilku dniach od urazu, kiedy wyraźnie zarysowała się granica martwiczych tkanek. Wówczas, po ich usunięciu i oczyszczeniu rany pokrywano, ubytki przeszczepami skóry i lokalnymi płatami uszypułowanymi.

Kolejnym powodem odmowy były amputacje pojedynczych palców, które nie wchodzą w zakres działalności serwisu. Urazy te są tak częste, że ośrodki replantacyjne nie mogą ich przyjmować z powodów logistycznych. Nie dotyczy to jednak kciuków. Replantacje pojedynczych palców są wykonywane w ramach normalnej, dyżurowej działalności dla terenu macierzystego województwa. Amputacja pojedynczego palca (z wyjątkiem kciuka) jest względnym wskazaniem replantacji także w świetle wytycznych Europejskiej Federacji Towarzystw Chirurgii Ręki (FESSH) [4]. 
Jak wynika z wcześniejszej pracy, uratowanie amputowanego pojedynczego palca nie przynosi lepszych rezultatów dla czynności ręki niż proste zaopatrzenie kikuta, a jest znacznie bardziej czasochłonne i kosztowne [6]. Według danych zawartych w tabeli 1, pacjenci z większą liczbą amputowanych palców byli częściej przyjmowani do replantacji. Było to spowodowane bardziej względami humanitarnymi niż merytorycznymi: przy amputacji trzech palców, replantacja jednego lub dwóch nie poprawia istotnie czynności ręki, w porównaniu z terminalizacją [6]. Niektórzy jednak uważają, że pozostawienie nawet sztywnych palców może umożliwiać lepszy chwyt przy zachowanym sprawnym kciuku.

Następną przyczyną odmów były przypadki amputacji ręki u chorych z urazami wielonarządowymi, z towarzyszącymi obrażeniami czaszki, klatki piersiowej i brzucha. Tacy chorzy wymagają przede wszystkim zabiegów ratujących życie i nie powinni być narażeni na kilkugodzinny zwykle transport, a następnie długą procedurę replantacyjną. Nie należy ryzykować życia pacjenta, próbując ratować kończynę czy też palec. Z podobnych powodów również odmówiono przyjęcia pacjenta w podeszłym wieku, obciążonego poważnymi chorobami towarzyszącymi.

Amputacje kończyny dolnej nie były przyjmowane z dwóch powodów. Klinika Chirurgii Ogólnej i Chirurgii Ręki PUM ma profil, jaki wskazuje jej nazwa, a urazami kończyny dolnej zajmują się oddziały ortopedyczne. Drugim powodem jest zwykle niekorzystny wynik replantacji kończyny dolnej, jeżeli się ją podejmie: występują zwykle problemy ze zrostem kości, nie wraca unerwienie i ruchomość stopy. Taka kończyna jest znacznie mniej użyteczna dla chorego niż dobra proteza. W odróżnieniu od kończyny górnej standardowym postępowanie przy amputacjach kończyn dolnych u dorosłych jest zaopatrzenie kikuta i szybkie protezowanie. Wyjątek od tej reguły stanowią dzieci, u których podejmuje się próby replantacji, z różnym powodzeniem.

Wiek nie odgrywał istotnej statystycznie roli przy kwalifikacji do replantacji: żaden z pacjentów nie został odrzucony z powodu wieku. W tej grupie chorych można się jednak spodziewać gorszych wyników replantacji, zarówno pod względem przeżywalności kończyn, jak i jej późniejszej czynności. Starsze osoby, szczególnie z mniejszych miejscowości lub wiosek, mają ograniczony dostęp do rehabilitacji i są mniej zmotywowane do intensywnego wysiłku, aby odzyskać sprawność przyszytej ręki. Oznacza to, że kończyna wprawdzie przeżyje, ale korzyść z niej będzie niewielka. Ponadto chorzy w podeszłym wieku są bardziej podatni na powikłania ogólnoustrojowe: krążeniowe i oddechowe, co może zdarzać się stosunkowo często po wielogodzinnej operacji, jaką jest replantacja. Nie bez znaczenia jest także fakt, że wielu pacjentów (zwłaszcza mężczyzn) w podeszłym wieku to długoletni palacze, a to jest to istotny czynnik zmniejszający szanse na przeżycie przyszytej ręki. Jednak niekiedy zdarzają się ponad 70-letnie osoby w dobrej ogólnej kondycji, którym replantacja nie powinna być odmawiana, szczególnie w przypadku odcięcia całej kończyny lub np. 4 palców. Najstarszy pacjent, któremu w klinice wykonano udane przyszycie 2 z 4 amputowanych palców, miał 82 lata [7].

W pracy badano wpływ odległości szpitala kierującego do ośrodka replantacyjnego. Pacjenci z województwa zachodniopomorskiego byli częściej kwalifikowani niż ci z odleglejszych części Polski. Jest to nieoczekiwany wynik, gdyż rzadko duża odległość była powodem odmowy przyjęcia do replantacji. Niekiedy jednak transport, nawet lotniczy na odległość 700-800 km, trwa ponad 8 godzin, co jest względną granicą możliwości przeżycia niedokrwionej kończyny, nawet przy jej optymalnym schłodzeniu. Ma to większe znaczenie w przypadku amputacji części zawierającej mięśnie (proksymalnie od śródręcza) niż np. palców, które można z powodzeniem replantować nawet po 12-15 godz. Nigdy jednak nie odmówiono przyjęcia tylko ze względu na zbyt dużą odległość od ośrodka replantacyjnego.

Jest zrozumiałe, że wszystkie zainteresowane osoby: okaleczony pacjent, jego rodzina, ale także bezpośrednio zaangażowany w sprawę lekarz uważają za najlepsze rozwiązanie dostarczenie chorego do ośrodka referencyjnego, niestety, często odległego o kilkaset kilometrów, aby tam dokonano oceny i podjęto próbę ratowania kończyny. Jednak trzeba pamiętać, że procedura jest czasochłonna, kosztowna (transport lotniczy), wymaga zaangażowania wielu ludzi i znacznych środków, a niekiedy bywa niebezpieczna, np. niesprzyjające warunki atmosferyczne dla samolotu. $\mathrm{Z}$ doświadczenia wiadomo także, że co najmniej 1/3 amputowanych palców i rąk a priori nie nadaje się do przyszycia z różnych przyczyn, które już wymieniono. W każdej z tych sytuacji transport do ośrodka replantacyjnego jest stratą czasu, niepotrzebnym wydatkiem i narażeniem na ryzyko pacjenta, załóg ambulansów i samolotu. Dlatego taka decyzja powinna być podejmowana odpowiedzialnie, racjonalnie i z wykorzystaniem wszystkich możliwości prawidłowej oceny szans na powodzenie operacji. Opracowane przez jednostki uczestniczące w serwisie zasady zgłaszania przypadków pozwoliły na znaczne zredukowanie liczby niepotrzebnych przyjęć do ośrodków referencyjnych urazów niedających szans na przeprowadzenie replantacji.

W krajach Unii Europejskiej nie ma jednolitego systemu udzielania pomocy w przypadkach amputacji rąk W jednych opiera się on na kilku wydzielonych ośrodkach referencyjnych, w innych replantacje są wykonywane przez wszystkie oddziały dysponujące serwisem mikrochirurgicznym. Trzeba stwierdzić, że skala amputacji kończyn jest znacznie mniejsza w krajach „starej Unii” niż w tzw. krajach postkomunistycznych [1]. Wynika to ze stosowania bardziej zaawansowanych technologii w przemyśle, eliminujących pracę z niebezpiecznymi urządzeniami, tradycji przestrzegania zasad bezpiecznej pracy, a także z mniejszego rozpowszechnienia niebezpiecznych urządzeń (przede wszystkim pił tarczowych) wśród ludności. W Wielkiej Brytanii operacje amputowanych kończyn są wykonywane w ok. 20 szpitalach posiadających oddziały chirurgii plastycznej i rekonstrukcyjnej lub ortopedii, które mają doświadczenie w chirurgii ręki i mikrochirurgii (stanowi to ok. $20 \%$ 
wszystkich oddziałów chirurgii ręki). Zwykle pacjent jest dostarczany do najbliższego takiego ośrodka ambulansem, a transport lotniczy rzadko jest konieczny. W Niemczech istnieje ok. 15 ośrodków zajmujących się replantowaniem kończyn. Są to oddziały chirurgii ręki, chirurgii urazowej, plastycznej i rekonstrukcyjnej lub ortopedii, które mają doświadczenie w operacjach mikrochirurgicznych. Jednak, podobnie jak w Wielkiej Brytanii, nie są one zorganizowane w obrębie spójnego systemu i ich działalność nie jest koordynowana. We Włoszech istnieje dobrze zorganizowany system ok. 15 ośrodków replantacyjnych, koordynowany przez włoskie Towarzystwo Chirurgii Ręki. W każdej prowincji (odpowiednik województwa) jest co najmniej jeden taki ośrodek, ich działalność jest systematycznie oceniana, a sprawozdania są publikowane corocznie na stronie internetowej włoskiego Towarzystwa Chirurgii Ręki.

Wyniki pracy wskazują, że odmowy w ramach dyżuru replantacyjnego dotyczyły przede wszystkim urazów niezagrażających przeżyciu uszkodzonej kończyny, bardzo dystalnych amputacji, amputacji pojedynczych palców i przypadków znacznego zniszczenia części amputowanej. Uzasadnieniem takiego wyboru były względy merytoryczne i ekonomiczne - brak realnych szans na powodzenie replantacji i niekorzystny rachunek potencjalnych korzyści wobec znacznych kosztów.

\section{Piśmiennictwo}

1. Żyluk A.: Organizacja i działalność Serwisu Replantacyjnego dla amputacji rąk w Polsce. Chir Narz Ruchu Ortop Pol. 2013, 78, 71-76.

2. Żyluk A., Jabłecki J., Romanowski L., Mazur A.: Raport z trzyletniej działalności serwisu replantacyjnego dla amputacji rąk w Polsce. Pol Przegl Chir. 2012, 84, 574-581.

3. Żyluk A., Janowski P.: Wyniki leczenia złożonych, wielotkankowych uszkodzeń rąk. Pol Przegl Chir. 2011, 83, 153-165.

4. Sebastin S.J., Chung K.C.: A systematic review of the outcomes of replantation of distal digital amputation. Plast Reconstr Surg. 2011, $128,723-737$.

5. Datiashvili R., Knox K.R., Kaplan G.M.: Solutions to challenging digital replantations. Repl Transpl Clin Plast Surg. 2007, 34, 167-175.

6. Dec P., Bartosik K., Chrąchol J., Puchalski P., Żyluk A.: Porównanie wyników replantacji lub rekonstrukcji i terminalizacji w leczeniu amputacji palców rąk. Ann Acad Med Stetin. 2013, 59, 49-52.

7. Walaszek I., Szlosser Z., Żyluk A.: Successful replantation of two out of four amputated fingers in an 80 years-old patient: a case report. Handchir Mikrochir Plast Chir. 2014, submitted. 